\title{
Democracy and state of exception in light of the dialectic between demos and population
}

\author{
Jonas Heller
}

Published online: 22 October 2018

\begin{abstract}
Within democratic orders, it is the declared aim of a state of exception to secure or restore the endangered foundation of democracy. The provided measures are, however, undemocratic insofar they directly affect individual rights as the principle on which democracy is based: By suspending rights, the state of exception treats individuals not as members of a democratic community (demos), but as parts of a population which has to be secured. Whereas individual rights enable individuals to be part of the demos, the state of exception - by restraining rights - enforces a politics of population. In my article, I show in what way individual rights, too, are used as a strategy of governing the population. Referring to the history of individual rights in the early modern period, I describe a specific form of alienation of individual rights. I argue that this alienation consists in the separation of a private from the political component of individual rights. This alienation is the reason for a dialectical shift from demos to population which occurs in an extreme form in the state of exception. Against this background, the question of the state of exception and the question of individual rights appear in an unfamiliar but crucial relation. In order to oppose the dialectical shift and the misuse of exceptional measures, I claim it necessary to insist on the inextricable link between the private and the political component of individual rights - that is to extend the domain of democracy.
\end{abstract}

\section{Demokratie und Ausnahmezustand im Licht der Dialektik von demos und Bevölkerung}

Zusammenfassung Das erklärte Ziel eines Ausnahmezustands besteht in demokratischen Rechtsstaaten darin, das bedrohte Fundament der demokratischen Ordnung

\footnotetext{
Dr. J. Heller $(\bowtie)$

Exzellenzcluster "Die Herausbildung normativer Ordnungen", Goethe-Universität Frankfurt, Max-Horkheimer-Straße 2, 60323 Frankfurt am Main, Germany

E-Mail: jonas.heller@normativeorders.net
} 
zu sichern oder wiederherzustellen. Die mit diesem Ziel verbundenen Maßnahmen sind insofern undemokratisch, als sie direkt die individuellen Rechte und damit das Prinzip tangieren, auf dem die Demokratie beruht. Im Ausnahmezustand werden die Individuen - durch die Suspension ihrer Rechte - nicht als Mitglieder einer demokratischen Gemeinschaft (demos), sondern als Bestandteile einer zu sichernden Bevölkerung betrachtet. Befähigen die individuellen Rechte die Menschen dazu, Teil eines demos zu sein, forciert der Ausnahmezustand dagegen eine Politik der Bevölkerung. In meinem Aufsatz zeige ich, inwiefern individuelle Rechte allerdings nicht allein im Zustand ihrer Beschränkung, sondern auch ihrer Gewährung als Mittel genutzt werden können, um Bevölkerung zu regulieren. Hierzu beschreibe ich im Rückgriff auf die frühneuzeitliche Geschichte individueller Rechte eine spezifische Form ihrer Entfremdung, die in einer Spaltung innerhalb der Rechte besteht: in der Trennung ihres privaten von ihrem politischen Moment. In dieser Entfremdung liegt die Möglichkeit für einen dialektischen Umschlag vom demos zur bloßen Bevölkerung, der sich im Ausnahmezustand in extremer Form realisiert. Ausnahmezustand und individuelle Rechte erscheinen vor diesem Hintergrund in einer ungewohnten, doch für ihr Verständnis entscheidenden Beziehung. Dieses Verständnis hat auch praktische Konsequenzen. Um dem Missbrauch von Ausnahmemaßnahmen entgegenzutreten, ist es gerade notwendig, auf dem unlösbaren Zusammenhang des privaten und des politischen Moments individueller Rechte zu insistieren - und das heißt, den Bereich der Demokratie zu erweitern.

\section{Introduction}

The state of exception is opposed to democracy in two ways: Firstly, because there is a shift of power from the legislative to the executive; general laws which result from a democratic process are substituted by particular measures executed by the government. Secondly, the state of exception stands in opposition to democracy insofar as practices which are indispensable for a democratic formation of the political will (e.g. the freedom of assembly) are restricted.

Both of these anti-democratic aspects reduce individual rights: The extension of executive power affects the rights to political participation. The constraint of fundamental democratic practices affects the rights to private freedom. These two classes of individual rights - political and private rights - define and enable a twofold, normative foundation of democracy. This twofold foundation consists, in the terminology of Jürgen Habermas (1999, pp. 301-303; I will come back to this in Sect. 2), in two coupled autonomies: public autonomy on the one hand, private autonomy on the other. In the state of exception, both classes of individual rights and thus both types of autonomy are affected. Insofar the state of exception opposes these two intertwined autonomies on which democracy is based, the state of exception is antidemocratic in a fundamental sense. The state of exception neglects the demos itself. ${ }^{1}$ By demos I mean a collective in a specific political sense, a collective of individuals

\footnotetext{
${ }^{1}$ I use the Greek term demos for two reasons. Firstly, because demos, in its classical difference to ethnos, articulates a specific political character: Whereas ethnos denotes a concept of the people based on a common ('ethnic') descent, demos signifies a political community which is constitutively related to the
} 
who are acknowledged in their twofold autonomy, i. e. regarding the two mentioned dimensions of individual rights: private and political rights. ${ }^{2}$ The state of exception is anti-democratic because it is anti-foundational, opposed to the twofold foundation of democracy.

The justification that the state of exception interrupts democracy in order to restore its factual foundation - the order of the state itself - is not an argument against. This factual (and not: normative) foundation is not related to the demos and its autonomies, but to the population and its security: If the population is (or is considered to be) endangered, from the outside or from within, the factual foundation of democracy is at stake. In this situation, a state of exception enfolds measures aiming at an 'intact' population; individuals are then addressed as parts of this population which has to be secured. Securing the population means 'administrating' it. A crucial means to administer the population is the politics of limiting rights. Against this background, the following conclusion seems obvious: Whereas individual rights are on the side of the demos, the state of exception, which restricts individual rights, is on the side of the population.

In this article, I will argue that the question of demos and population has to be understood in a more complex way. Individual rights are not only related to the sphere of demos, but also to the population. They are, thus, not only the manifestation of the end of the state (a well-operating democratic order), but serve also as its means (as a strategy to govern the population). From this perspective, a different relation between individual human rights and state of exception comes to the fore. ${ }^{3}$ Their relation is not only a conflict between an end (democratic autonomy) and a means (undemocratic measures). It can neither be described just as a conflict between two ends: normative foundation of the democratic order on the one hand, versus factual

common formation of a binding political will. Secondly, because the term demos is indefinite, i. e. not oriented towards a particular political formation, e.g. the modern nation state. It can thus be applied as well to a historically different political situation as in the early modern period. Regarding the indefiniteness of the demos cf. the introduction of Catherine Colliot-Thélène: La démocratie sans démos, Paris: Presses universitaires de France (2011).

2 The third important class of rights, the rights to social goods and care, are often considered to belong to the rights of private freedom, namely as their presupposition (cf. Honneth 2011, pp. 142-143; Menke 2015, pp. 221-223; Waldron 1993). Insofar the satisfaction of material needs is a necessary condition for the realization of any autonomy, the class of social rights is constitutive for the actualization of both private and political rights (i.e. private and public autonomy).

3 As I focus on the relation between rights and state of exception, I am interested in those rights which are affected when states of exceptions are declared. By "individual human rights" I mean rights which protect individual freedom and security against the power of the state and which enable individuals to participate freely and equally in the formation of the political will of a democratic constitutional state. Such rights are, in particular, "civil and political rights" as formulated in the International Covenant on Civil and Political Rights (ICCPR), which was adopted by the United Nations General Assembly in 1966 and is in force since 1976. Examples are: the protection from arbitrary arrest or detention, the right to liberty of movement, the freedom to leave any country, the right to freedom of expression, the right of peaceful assembly, the right to freedom of association with others, and the right to privacy. Here, these "individual human rights" are considered insofar as they are a binding part (and foundation) of the legal order of nation states, i.e. insofar as they are constitutional rights. This is because the state of exception, as a legal instrument of the nation state, is the means of suspending these rights on a national level. Regarding the relation between the national and the international codification of individual human rights cf. Pieroth et al. (2013, pp. 12-14); Pollmann (2012, pp. 129-136). 
foundation of the democratic order on the other hand. Rather, individual rights and state of exception appear both also on the level of means. Of course individual rights are an important means of emancipation whereas the state of exception is a means of government. However, I am interested in the aspect in which they both appear as a means in the same sense: as a means of governing the population. This perspective in which individuals are collectively addressed as population is hence in the focus of this article. In this relation between individual rights and population, what I called private rights or rights to private freedom play the decisive role. Insofar individuals are addressed as demos, they are acknowledged in their political rights. The possibility to address them as population is a (and not the only) effect of private rights. Thus, these private rights are in the center of my interest here. However, as indicated, private and political rights are necessarily intertwined in a democratic state order, and so are demos and population.

I will proceed as follows: After pointing to the tension between individual rights and state of exception (2), I will outline their conjunction in the democratic constitutional state. As I argue, they both have a strong connection to state power. Whereas this may be clear regarding the state of exception, it is less obvious regarding individual human rights. Thus, the main intention of this step is to clarify the relation of these rights on the one hand and state power on the other (3). In light of this relation, I want to explain in what way not only the state of exception, but also individual rights function as a strategy of government. I will argue here that this strategy - the strategy of governing by means of rights - comes to the fore, if we pay attention to the two mentioned ways in which the people, as a collective, can be addressed: as demos, i.e. as active members participating in the political community, and as population, i.e. as an object of (economic) power. Insofar individual rights not only enable the people to be part of the demos, but address them also as population, they are not only a means of emancipation, but also a means of government (4). In the next step, I will argue that there is a tradition of 'governing by rights' which has accompanied the history of individual rights. Referring to the early modern period, I will focus on the legal 'management' of individual freedom as an important means of the evolving state (5). Against this background, I will, in the last step, shed light on the present relation between a politics of rights and a politics of exception. For it is this relation in which I see the dialectic between demos and population as indicated in the title (6).

\section{The tension between individual human rights and the state of exception}

Apparently, human rights and the state of exception are conflicting legal phenomena. They pursue different goals. Human rights, at least in their classical form as freedom rights, aim at the protection of the individual. The state of exception, however, aims at the preservation of the political and juridical order of the state. The state of exception is precisely the situation in which the mere difference between these two aims turns into a conflict. For the state of exception not only brings an extension of executive competences but also goes along with the limitation and suspension of 
individual rights: Constitutional individual rights are suspended in order to preserve the state. In Carl Schmitt's words: "[I]f the existence of the constitution is threatened, it must be protected by means of a temporal suspension of the constitution." ${ }^{4}$ At this point, it becomes clear that individual rights and the state of exception are not only different and conflicting regarding their aim. They are different as well regarding their position within the legal system of the constitutional state, of the Rechtsstaat or Etat de Droit. Individual rights, in their institutionalized shape of constitutional rights, are considered as fundamental principles of the constitutional state; they are positioned at the ground or in the center of the legal order. ${ }^{5}$ The state of exception, however, is positioned at the edge of the legal order: In the often-quoted beginning of his book Political Theology, Schmitt speaks of the state of exception as a "borderline case". ${ }^{6}$ Individual rights and the state of exception are, against this background, opposing phenomena in two regards: Firstly regarding their aim, secondly regarding their position within the legal order of the constitutional state: Whereas individual rights aim at protecting the individuals and their freedom, the state of exception aims at restoring a stable order as the condition of individual freedom; and whereas individual rights belong to the principles of this order, the state of exception revokes these principles and breaches the order.

\section{State of exception and individual rights within the framework of the nation state}

There is, however, also a clear conjunction between individual rights and the state of exception. This conjunction is the framework of the state. Regarding the state of exception, this may immediately be plausible. And regarding individual rights? The fact that individual human rights are meant to protect individuals against the state does not mean that they are external to the state: In the form of constitutional rights (which is relevant here, cf. footnote 3), human rights are guaranteed by the state itself. For human rights the protection by the state is crucial. The importance of the enforcement of rights by the power of a state was Hannah Arendt's central point in her article Es gibt nur ein einziges Menschenrecht (1949) as well as in her book about The Origins of Totalitarianism (1958, Chap. 9). ${ }^{7}$ Human rights are meant to limit the power of the state, but conversely, the protection they provide relies on

\footnotetext{
4 Schmitt refers here to the general justification of the commissarial dictatorship; Schmitt (2006, p. 133, transl. J.H.).

5 According to Schmitt's Constitutional Theory, constitutional rights belong to the "Rechtsstaat component of the modern constitution". Together with the principle of separation of powers, they build the "essential content of the Rechtsstaat component" (Schmitt 2008, p. 170). The state of exception is the political breach of this Rechtsstaat component - and a violation of its essential components; for Schmitt, it is the situation in which the political component proves to be the predominant one. The superiority of the political component (and the inferiority of the Rechtsstaat component) of the legal order is the defining theme of Schmitt's book Political Theology (Schmitt 2005).

6 As a "borderline case", the state of exception is appropriate to define "sovereignty" as a concept "pertaining to the outermost sphere" of the legal order (Schmitt 2005, p. 5).

7 In both texts, Arendt emphasizes that human rights only have an impact when they are civil rights, i.e. the rights of citizens, guaranteed by the state they belong to. Different from the situation of 1949, the
} 
state power itself. This leads to a familiar justification of the state of exception: Rights have to be suspended in order to uphold the state order, which is solely able to guarantee the freedom they provide in the first place. This is one way to explain why human rights are, in the form of constitutional individual rights, not external to the state: Rights need the force of the state to become reality.

However, not only the state serves the realization of individual rights, but rights are also of crucial normative significance for the legitimacy of the state. Insofar a state claims democratic legitimacy ${ }^{8}$, the guarantee of individual rights is indispensable because democracy and human rights are inextricably linked. This point was persuasively made by Habermas in his book Between Facts and Norms, which is, as the German subtitle makes clear, about the democratic constitutional state ("demokratischer Rechtsstaat"). ${ }^{9}$ Democracy, as a sphere of public autonomy, relies on private autonomy, i.e. on rights (and vice versa; cf. Habermas 1996, pp. 84-104). Private autonomy is a necessary condition to participate in the political formation of will; and it is the possibility to participate on which democracy is based. Democracy, understood as the rule of the demos in the above-mentioned sense, is the identity of those who rule and those who are ruled. In a constitutional state this means: The citizens are empowered to determine the laws which, under the rule of law, are applied to them. The precondition of this democratic sovereignty (public autonomy) is an institutionalized legislation process based on human rights (private autonomy). From a discourse-theoretic perspective, this 'public' function of individual rights is regarded as their decisive aspect: "The substance of human rights then resides in the formal conditions for the legal institutionalization of those discursive processes of opinion- and will-formation in which the sovereignty of the people assumes a binding character." (Habermas 1996, p. 104) Accordingly, individual rights are the precondition of the democratic state concerning its legal form. So, the state needs rights for the following reason: The legitimation of the public will of the state is conditioned by the private freedom of the individuals who constitute "the people". In this democratic-theoretic account, which is focused on legitimation, the individuals figure as people in the sense of demos: of the active political subjects.

\section{Population: The 'subject-object' of economic government}

There is, again, another aspect in which the state needs the rights of individuals: Individual rights, in the form of private individual rights (rights to freedom), are not only important for the legitimation, but also for the existence of the state. In this perspective, the individuals do not appear in the form of the demos, but of the population. This is the focal point of my interest here: Demos and population are two different ways to consider the individuals, appearing as a collective entity towards

international human rights protection has developed substantially to this day: Statelesness does not mean any more to be expelled from the legal sphere (cf. Brunkhorst 1999, p. 174).

8 A non-democratic constitutional state is, according to Habermas (1996, Preface, p. xlii), impossible to be legitimate.

9 The original title of the German edition is: Faktizität und Geltung. Beiträge zur Diskurstheorie des Rechts und des demokratischen Rechtsstaats (1992). 
the state. How can this difference be described? At first glance, it may seem that the individuals as demos, as the people in the political sense, are active whereas the population is passive: The concept of demos denominates an entity which governs, and the population an entity which is governed. How the population emerged as an issue of government, is a question addressed extensively by Michel Foucault, especially in his lectures on "Security, Territory, Population" (Foucault 2007). The remarks of Foucault are particularly illuminating because they insist that we cannot think of the population as merely passive. It is for this reason he speaks of the population not as the 'object' of government, but as its 'subject-object'. ${ }^{10}$ The term 'subject-object' signifies that the governed object is not simply heteronomous. It refers to cases in which being governed does not mean being passive. A 'subject-object' is governed through the stipulation of self-determined activity. In what follows, I will explain how Foucault conceives the 'subject-object' of the population. As will become clear, I consider it very convincing that Foucault explicates the ambiguous character of the 'subject-object' of the population by referring to the functional logic of the economic sphere. Foucault exposes the emergence of a new, economics-oriented mode of governing in the early modern period: Politics was conceived as a specific type of 'management'.

Considering what I have said above (3.), the demos is a subject-object; the individuals of the demos (the citizens) are subjects insofar they have the possibility to participate in the legislation process, and they are objects insofar the laws are applied to them. The population according to Foucault, however, is a 'subject-object' in a different way, since it appears in a different sphere: Population is not a legalpolitical category, not a category of public or private law, but a category of political economy (cf. Foucault 2007, pp. 74-79). The population is conceived (since the mid-18th century) as a phenomenon of vivid nature: not passive, not stable, not restful, but constantly endeavoring to satisfy its desires and needs. Thus, the population appears as dynamic, mobile, and active - and in this sense as a subject. As a subject, however, which is predictable: The collective subject of the population is seen as a natural process accessible to calculations and open to influence. As such, the population is an object of government. The strategies of this government are based on a specific knowledge which is, in the 18th century and famously by Rousseau, called "political economy" ${ }^{11}$ Political economy is the knowledge of the, as Foucault calls it, "naturalness" of the population (cf. Foucault 2007, pp. 70, 72, 74). The application of this knowledge takes shape as a "general management" (Foucault 2007, p. 97 and the like pp. 70, 73), consisting in 'security mechanisms' which are not primarily juridical, but intervene directly on the level of the factual reality:

\footnotetext{
10 The term 'subject-object was not brought up by Foucault. The concurrence of subject and object is, in the context of the concept of knowledge as self-knowledge, an important issue in the philosophical tradition. Georg Lukács (1967, p. 661), to pick out one example, speaks of a 'Subjekt-Objekt' referring to Hegels Phenomenology of Spirit.

11 Cf. Rousseau (1962 [1755]); and Foucault (2007, p. 106): "The constitution of a knowledge (savoir) of government is absolutely inseparable from the constitution of a knowledge of all the processes revolving around population in the wider sense of what we now call 'the economy'."
} 
These mechanisms do not tend to a nullification of phenomena in the form of the prohibition, 'you will not do this,' nor even, 'this will not happen,' but in the form of a progressive self-cancellation of phenomena by the phenomena themselves. In a way, they involve the delimitation of phenomena within acceptable limits, rather than the imposition of a law that says no to them. (Foucault 2007, p. 66)

The government of the population relies on such non-legal mechanisms. Not only since the 18th, but already since the 15th and 16th century, there is, according to Foucault, a shift from the state of justice into the "administrative state" (cf. Foucault 2007, pp. 108-109). There is a direct correlation between the administrative approach and the supposed nature of what is approached. The administrative state is a state operating through 'management': direct measures outweigh legal regulations. The population addressed by these measures "is not, then, a collection of juridical subjects" (Foucault 2007, p. 74). Insofar the individual is a component of the population, it does not figure as the 'subject of right' but simply as 'man': "man is to population what the subject of right was to the sovereign" (Foucault 2007, p. 79).

Foucault's account of the emergence of the population and of its relation to the economic sphere are highly convincing. The point in which I differ and which I want to develop in a different direction than Foucault comprises three linked aspects: Firstly, Foucault assumes that the economic individual stands in contrast to the subject of right; secondly and relatedly, he assumes that the population consists of economic individuals and not of subjects of right. Thirdly, Foucault suggests that the emergence of the population necessarily ends juridical sovereignty. Unlike Foucault, I want to argue that there is indeed an important relation between the legal sphere and the government of the population. Precisely, the opposing juridical figures, individual rights and the state of exception, taken together reveal the legal character of governing the population. In this respect then, (private) individual rights and the state of exception are complementary (not opposing) phenomena, namely insofar as they are both used as legal instruments to govern the population.

In the case of the state of exception, the link to the population is more evident. The state of exception is a means by which the state power acts directly, i.e. not mediated by general laws, upon the population. The juridical measures which substitute general laws ${ }^{12}$ and the deprivation of rights are two ways in which the state forms the population: The exceptional measures restrict democratic action and disempower the individuals as demos, i.e. treat them only as population; by the deprivation of individual rights the state of exception protects this population - it excludes from it those individuals who could disrupt it. On the other hand - this is the argument I will develop in what follows - , it is precisely the provision of individual rights which generates the population. Not only the state of exception governs the population by 'managing' individual rights. Individual rights themselves appear, in a historical perspective, as a means of governing the population in a managerial way.

\footnotetext{
${ }_{12}$ As a systematic strategy, the substitution of general laws by particular measures was a key feature of the totalitarian government during the period of National Socialism; cf. Neumann (1936, pp. 570-578).
} 


\section{The tradition of governing by rights}

The fact that the phenomenon of the population emerges in the 17th century is not only stated by Foucault. The historian and political scientist Hans Maier writes, referring to a treatise of Georg Obrecht, a Strasbourg councilman from the beginning of the 17th century: "For the first time, the individual independent from its estatesbased relations, the abstract 'population' is discovered as object of management [Verwaltung]." ${ }^{13}$ This management of the population aims at the enhancement of the state's strength: The people are 'population' insofar as they are considered as matter of the state. This is reflected as well in Latin treatises of the same time. Christian Liebenthal, a scholar from the German town Gießen, wrote in 1619: "Distinguitur proinde civitas a republica ut materia a forma." 14 ("Thus, the civitas [the citizenry, the people, in my reading: the population] is distinguished from the republica [the republic, the state] like the matter from the form." transl. J.H.) It is important to note, firstly, how this matter is formed and, secondly, how it serves the enhancement of the state's strength. Maier remarks, as the above quote shows, that the abstract population consists of individuals which are removed from their embeddedness within estates-based relations. This liberation is achieved by the juridical figure of individual rights (cf. Luhmann 1981, p. 47). As bearer of rights, the individuals appear as equal; as equals, they are part of the abstract population. Other than Foucault suggests, the subjects of right - the 'legal persons' (Latin: personae) and not 'men' - figure as components of the population. The population as the matter of the state is formed by guaranteeing individual rights. Individual rights not only enable the people to actively participate in the demos and to hereby constitute it (cf. above, 3.). They are also the means to constitute the population; the individuals are part of the population insofar they are bearers of rights. Thus, the difference between demos and population is not that one belongs to the legal and the other to the economic sphere. Both concepts are linked to the legal sphere, i.e. to the concept of the 'person' as bearer of rights. However, insofar as individual rights are considered simply or mainly as a means to an economic end, the individuals are treated as population (and not as demos).

Individual rights are also important to answer the question how the population serves the enhancement of the state's strength. In the 16th and 17th century, the literature about taxes and the theories about the justification of taxes provide evidence that the financial situation of the prince and the wealth of the state can be increased by supporting the population's economic activity. As early as around 1600, in the agrarian sector the idea evolved that there is a higher yield when a field is leased to a peasant instead of being cultivated by soccage. The - fiscal - enhancement of the state, thus, is sought in and achieved through economic freedom, and economic freedom is provided by individual rights. It is therefore in the discussions on tax theory that the conception of irrefutable individual rights gains importance (cf.

\footnotetext{
13 Maier (1980, p. 130), transl. J.H. The treatise of Georg Obrecht is titled Fünff Vnderschiedliche Secreta Politica; it was privately printed in 1617 and publicly edited in 1644 .

${ }^{14}$ Christian Liebenthal, Collegium politicum in quo de societatibus, magistratibus, juribus majestatis, et legibus fundamentalibus [...] tractatur, Giessen 1619; quoted from Schulze (1987, p. 175).
} 
Schulze 1987, pp. 174-175). Against this background we can note, beyond Foucault, that precisely individual freedom rights enhance the ('natural') productivity of the population. It is thus in a legal sense that the population is to be conceived as a 'subject-object': It is a subject because it gains freedom through rights, and it is an object because it is governed through rights. ${ }^{15}$ The productive 'security mechanisms' are not only, as Foucault seems to suggest, outside the law, but effective within the legal sphere itself.

From the perspective of the early modern state, individual rights have a double impact. First: By establishing legal equality, the population is made countable and accessible to taxation. Second: Insofar as rights provide (economic) freedom, they foster economic activity and help to increase profits and thus tax income. If for the modern concept of law, not the laws, but the orientation toward rights is characteristic ${ }^{16}$, then in the described perspective it becomes clear, that individual rights admittedly belong to the individuals, but their purpose or end is not only the individual but as well the population, and in this sense they are not an end in themselves, but a means. The concern of government, this is the strong point made by Foucault, is the 'security' of the population, i.e. to secure its 'natural' productivity. The instrument to do this is managing individual freedom. This implies not only to provide freedom but, if necessary, to limit it. With regard to the 18th century, Foucault states: "The integration of freedom, and the specific limits to this freedom within the field of governmental practice has now become an imperative." (Foucault 2007, p. 353) From this perspective of governing the population, it seems appropriate to limit rights when they fail to serve their purpose, i.e. to ensure the security of the population. With the issue of limiting and suspending rights, I have reached again the question of the state of exception which characteristically goes along with the suspension of individual rights.

\section{From prosperity to security: The state of exception and the endangered population}

It is neither historically nor systematically appropriate to without further ado transfer the observations considering the early modern government of population to regimes of state of exception in the constitutional nation states of the 20th century and the present age. But it can help to shed light on the question which is debated in the context of states of exception and, more generally, of increasing security

\footnotetext{
15 Regarding this 'subject-object', however, Foucault does not address how (or that) it is constituted by the juridical figure of individual rights. The reason for this may be that Foucault does not consider fundamental rights to be juridical in the proper sense. This becomes clear at the end of the last lecture of the series: "There must be a moment when, breaking all the bonds of obedience, the population will really have the right, not in juridical terms, but in terms of essential and fundamental rights, to break any bonds of obedience it has with the state and, rising up against it, to say: My law, the law of my own requirements, the law of my very nature as population, the law of my basic needs, must replace the rules of obedience." (Foucault 2007, p. 356) Foucault does not take into consideration that the rights in juridical terms could be the 'law' of the population: the law of its formation and of its 'management'.

16 Cf. Strauss (2005, pp. 181-183); Luhmann (1981); Habermas (1996); Menke (2015).
} 
measures: the question of security versus freedom. This question is debated as a conflict between two rights of the individual: the right to security and the right to freedom. The state of exception declares a situation in which the right to freedom impairs the right to security. Thus, the right to freedom has to be limited in order to guarantee the right of security. This is the claim associated with the declaration of a state of exception.

This logic of the exception has to be questioned in two aspects: Firstly, security does in this context not appear as an individual right, but as a collective fact - not the individual security, but the security of the population is in focus of the exceptional measures (cf. Wihl 2017, p. 68; Frankenberg 2010, pp. 243-247). Secondly, the individual freedom which is to be limited - or the rights which are to be suspended - are only the rights of 'some': of those who endanger the population (or the power of the rulers) and hence are outsiders who do not belong to 'us' (as the population) (cf. Frankenberg 2017, pp. 5-6 and pp. 17-18).

My assumption is that the history of governing the population sheds light on these two aspects. I start with the second aspect and want to refer once again to Foucault: In the context of the 18th century, those who do not belong to the population are called 'the people', 'le peuple', 'das Volk': "The people comprise those who conduct themselves in relation to the management of the population, at the level of the population, as if they were not part of the population as a collective subject-object". (Foucault 2007, pp. 43-44) As I have argued here, the modern (i.e. 'free') population is a collective entity substantially constituted by individual rights - since the exercise of rights serves the end of a wealthy population. Conversely, it seems appropriate to limit the rights of those who act "as if they were not part of the population". The provision of individual rights and their suspension appear, from this perspective, as two ways of managing the population - of defining who belongs to it and who is to separate from it. Providing rights is - regarding the systematic idea, not the historical reality (cf. van Dülmen 1997, p. 145) - an operation of indiscriminate equality: It is the idea of rights that all human beings, as legal persons, are equal, i. e. equally free. Suspending rights, to the contrary, is an operation of inequality. The suspension of rights does not imply that the rights of all are equally suspended, but that some are deprived of their rights more than others. As an example, the state of emergency (état d'urgence) which was declared in France in November 2015 involved a clear preemptive focus on Muslim people (cf. Jobard 2017 and Wihl 2017, p. 76). Regarding the question of security versus freedom, we can note: In state of exceptions, whereas the security is not that of the individuals but of a collective, the affected freedom is regularly not that of all but that of some individuals.

In a state of exception, the limitation and deprivation of rights is always directed towards those who are not considered to belong to the population. The state of exception, however, is not only part of a politics of rights insofar it denies the rights of some. It also operates on the general presupposition of rights, more precisely: on the presupposition of the legal equality established by rights. In a state of exception, the inequality implemented in order to manage the population is systematically made invisible behind the equality of the concept of 'legal person': When an individual is deprived of rights, it is nevertheless addressed as equal, i.e. as a legal person. This legal equality covers that we are not all equally affected by the deprivation of rights 
occurring in state of exceptions. In fact, as indicated, specific groups with specific origin, color of skin, religion etc. are affected more than others because they are considered to endanger the security of the population (and thus not to be equally part of it). The equality of the legal person (of men as bearer of rights) is in these cases the means to establish inequality.

The state of exception is a situation in which the individuals are only regarded as - either appropriate or disruptive - parts of the population. In contrast to general laws, the measures of the exception allow to treat the individuals 'individually', depending on their assumed impact on the population; individuals are regarded only as a means. In this way, they lose their political quality which is to be a constitutive part of the demos. The state of exception is, for this reason, the point where the dialectic between demos and population takes place. It occurs when the issue of managing the population gains a separate existence apart from the political question of demos. Individual rights are then not provided as such, but reduced to their functionality, that is only provided insofar as they serve the population. The state of exception is not the general suspension of rights, but rather a specific form of their unequal 'distribution'. It is this inequality of distribution which extinguishes the quality of demos as a community of equal members. It is the idea of rights that rights are equally guaranteed for all, in other words: to constitute a demos of equally free and equally empowered individuals. In this orientation toward the demos, the idea of rights transcends any functionality, any reduction of rights to a means. The politics of rights which is enacted in the state of exception breaks with this idea of rights. By unequally guaranteeing rights, it cuts their relation to the demos. The dialectic of demos and population is, hence, an alienation of rights. Alienation occurs when things or aspects substantially belonging together are separated (or perverted). I suggest that the mentioned alienation of individual rights is rooted in a separation of private and political rights. 'Within' rights, the private is isolated from the political component. The political component enables to participate in the process of the formation of a political will. In this way, political rights authorize to be an equal part of the political community. The idea of being equal is the idea of being an equal part. Equality itself is a political idea, realized only in the political realm. Private rights (the rights to private freedom) depend on this political idea because they also are equal rights, rights to equal freedom. An unequal limitation (i.e. unequal provision) of freedom, as it is the characteristic of the state of exception, indicates that private rights are separated from the political component of individual rights. From the normative perspective of democracy, political and individual rights belong inextricably together: they cannot be separated. Historically, however, they do not emerge in their systematic connection. Before the 18th century, private individual rights were not seen in relation with political rights; they had nothing to do with an empowerment to political participation and political equality. The state of exception shows how profoundly inequality is still a part of rights: Besides the fact that rights to political participation are reserved to the citizens of the nation states, private freedom rights, which are considered to be even more fundamental, also are guaranteed to a different extent. The situation of the state of exception and the alienation of rights are part of the same problem: to end the politics of inequality, which is often applied in state of exceptions, it is necessary to end the inequality of rights. For this purpose, 
the nexus between private and political rights has to be reinforced and defended. This involves as well to take seriously what Arendt (1958, pp. 296-297) claimed: the right of everyone to belong to a political community.

\section{Conclusion}

In order to oppose the alienation of rights, it is necessary to be critically aware of three different points: Firstly, it has to be taken into account that there is a connection between individual rights and the question of population. For it is this connection which enables a dissolution of the political quality of rights, i.e. their dialectic decoupling from the demos. This dialectic remains unseen if individual rights are only considered in a normative perspective (only in terms of the demos), and not historically in their function for the population. Secondly, it should not be ignored that the state of exception does not imply a general (and in this sense: 'equal') suspension of rights, but their individual distribution. This unequal distribution acts on the basis of the equality instituted by rights: the measures of the exception address all individuals as 'legal persons'. They address them as equals, but not equally. The third point is the most fundamental: It has to be noticed clearly that demos and population actually are two different ways of addressing the individuals as a collective. In a current populist understanding of democracy precisely this difference is denied. ${ }^{17}$ Whereas demos is a concept of political inclusion, population is a concept of separation - and of exclusion of those who allegedly do not benefit the population (because they endanger its productivity or security). Against this background, the dialectic occurring in the state of exception - and the alienation of rights which goes along with it -, has to be opposed by detaching individual rights from the idea of an exclusive population and to bind them more decisively to an inclusive demos. One step to do so is the critique of a populist identification of demos and population. It is necessary to expound in detail the anti-democratic logic of continuity between rights and state of exception - a continuity which is legitimized with reference to democracy, however rooted in population policy.

Acknowledgements I thank Katharina Hoppe and Esther Neuhann for their careful readings and productive comments, as well as the participants of the Paris conference "State of Exception - An Overview" (November 2017) for their critical and helpful remarks.

\section{References}

Arendt, Hannah. 1949. Es gibt nur ein einziges Menschenrecht. Die Wandlung. Eine Monatsschrift 6(4):754-770.

Arendt, Hannah. 1958. The Origins of Totalitarianism, 2nd edn., Cleveland, New York: Meridian Books.

\footnotetext{
17 In his talk "Does democracy need to be more populist?" at The Hannah Arendt Center for Politics and Humanities at Bard College (New York, 13 October 2017), the philosopher and politician of the German right-wing party Alternative für Deutschland (AfD) Marc Jongen claimed that the Latin word populus signifies the same as the Greek word demos, namely the 'people'. This ignores the modern significance of populus/population and its historic development since the early modern period; cf. Jongen (2017, minute 16:36-16:55).
} 
Brunkhorst, Hauke. 1999. Menschenrechte und Souveränität—ein Dilemma? In Recht auf Menschenrechte. Menschenrechte, Demokratie und internationale Politik, ed. Hauke Brunkhorst, Wolfgang R. Köhler, and Matthias Lutz-Bachman, 157-175. Frankfurt am Main: Suhrkamp.

Colliot-Thélène, Catherine. 2011. La démocratie sans démos. Paris: Presses universitaires de France.

van Dülmen, Richard. 1997. Die Entdeckung des Individuums. 1500-1800. Frankfurt am Main: Fischer.

Foucault, Michel. 2007. Security, Territory, Population: Lectures at the Collège de France, 1977-1978. New York: Palgrave Macmillan. ed. Michel Senellart, transl. by Graham Burchell.

Frankenberg, Günter. 2010. Staatstechnik. Perspektiven auf Rechtsstaat und Ausnahmezustand. Berlin: Suhrkamp.

Frankenberg, Günter. 2017. Im Ausnahmezustand. Kritische Justiz 1:3-18.

Habermas, Jürgen. 1996. Between Facts and Norms. Contributions to a Discourse Theory of Law and Democracy. Cambridge: MIT Press. transl. by William Rehg.

Habermas, Jürgen. 1999. Über den internen Zusammenhang von Rechtsstaat und Demokratie. In Die Einbeziehung des Anderen. Studien zur politischen Theorie, ed. Jürgen Habermas, 293-305. Frankfurt am Main: Suhrkamp.

Honneth, Axel. 2011. Das Recht der Freiheit. Grundriß einer demokratischen Sittlichkeit, Berlin: Suhrkamp.

Jobard, Fabien. 2017. Ausnahmezustand und Anti-Terror-Recht in Frankreich. Bürgerrechte \& Polizei/ Cilip 112:42-49.

Jongen, Marc. 2017. Does democracy need to be more populist? Talk at The Hannah Arendt Center for Politics and Humanities at Bard College, New York, 13 October 2017. https://marcjongen.de/vortragam-hannah-arendt-center-new-york. Accessed 25 Feb 2018.

Luhmann, Niklas. 1981. Subjektive Rechte: Zum Umbau des Rechtsbewußtseins für die moderne Gesellschaft. In Gesellschaftsstruktur und Semantik. Studien zur Wissenssoziologie der modernen Gesellschaft, Vol. 2, ed. Luhmann, 45-104. Frankfurt am Main: Suhrkamp.

Lukács, Georg. 1967. Die "Entäußerung" als philosophischer Zentralbegriff der "Phänomenologie des Geistes". In Der junge Hegel. Über die Beziehungen von Dialektik und Ökonomie, Werke, Vol. 8, ed. Lukács, 656-693. Neuwied, Berlin: Luchterhand.

Maier, Hans. 1980. Die ältere deutsche Staats- und Verwaltungslehre, 2nd edn., München: C. H. Beck.

Menke, Christoph. 2015. Kritik der Rechte. Berlin: Suhrkamp.

Neumann, Franz. 1936. The governance of the rule of law. An investigation into the relationship between the political theories, the legal system, and the social background in competitive society. $\mathrm{PhD}$ thesis, The London School of Economics and Political Science. http://etheses.lse.ac.uk/668. Accessed 25 Feb 2018.

Pieroth, Bodo, and Bernhard Schlink, et al. 2013. Grundrechte. Staatsrecht II, 29th edn., Heidelberg: C.F. Müller.

Pollmann, Arnd. 2012. Menschenrechte, Grundrechte, Bürgerrechte. In Menschenrechte. Ein interdisziplinäres Handbuch, ed. Arnd Pollmann, Georg Lohmann, 129-136. Stuttgart, Weimar: Metzler.

Rousseau, Jean-Jacques. 1962. Économie Politique. In The Political Writings of Jean Jacques Rousseau, Vol. I, ed. Charles E. Vaughan, 237-280. Oxford: Basil Blackwell.

Schmitt, Carl. 2005. Political Theology. Four Chapters on the Concept of Sovereignty. Chicago: University of Chicago Press. transl. by George Schwab.

Schmitt, Carl. 2006. Die Diktatur. Von den Anfängen des modernen Souveränitätsgedankens bis zum proletarischen Klassenkampf. Berlin: Duncker \& Humblot.

Schmitt, Carl. 2008. Constitutional Theory. Durham, London: Duke University Press. transl. and ed. Jeffrey Seitzer.

Schulze, Winfried. 1987. Ständische Gesellschaft und Individualrechte. In Grund- und Freiheitsrechte von der ständischen zur spätbürgerlichen Gesellschaft, ed. Günter Birtsch, 161-179. Göttingen: Vandenhoeck \& Ruprecht.

Strauss, Leo. 2005. Natural Right and History. Chicago, London: University of Chicago Press.

Waldron, Jeremy. 1993. Liberal Rights: Collected Papers 1981-1991. Cambridge: Cambridge University Press.

Wihl, Tim. 2017. Der Ausnahmezustand in Frankreich. Zwischen Legalität und Rechtsstaatsdefizit. Kritische Justiz 1:68-80. 